\title{
Diagnosis and treatment of Paget's disease of bone: a mini-review
}

\author{
Diagnóstico e tratamento da doença de \\ Paget dos ossos: uma minirrevisão
}

Bruno Ferraz-de-Souza', Pedro Henrique Silveira Correa' ${ }^{1}$

\begin{abstract}
Paget's disease of bone (PDB) is a chronic progressive disorder of bone metabolism that may go undetected for many years, and endocrinologists should be alert to its clinical signs and promptly diagnose and treat PDB before it results in irreversible complications, such as deformity, fracture or neurological sequelae. Most commonly, PDB is suspected upon the incidental finding of elevated serum alkaline phosphatase levels or a radiographic abnormality in an otherwise healthy individual above 55 years of age. Some of these individuals may have symptoms such as bone pain or enlargement with increased warmth. In general, a basic laboratory evaluation of bone metabolism, plain radiographies of affected bones and bone scintigraphy are sufficient to corroborate the diagnosis. Antiresorptive therapy with bisphosphonates is the mainstay of treatment of symptomatic PDB, and intravenous zoledronic acid has emerged as an effective and safe treatment option, leading to sustained remission and improved quality of life. It is extremely important, though, to ensure calcium and vitamin D sufficiency before and during treatment in order to prevent hypocalcemia. The benefit of treating all asymptomatic patients is not clear, but treatment is warranted if the pagetic lesion is located in a site where progression to fracture, deformity, or compression would significantly impair the patient quality of life. This mini-review focuses on important aspects of the diagnosis and treatment of PDB. Arq Bras Endocrinol Metab. 2013;57(8):577-82
\end{abstract}

\section{Keywords}

Paget's disease of bone; bisphosphonates; zoledronic acid; osteoclast; antiresorptive treatment

\section{RESUMO}

A doença de Paget dos ossos (PDB) é uma doença progressiva e crônica do metabolismo ósseo que pode passar despercebida por muitos anos. Os endocrinologistas devem ficar alertas aos seus sinais clínicos e diagnosticar e tratar a PDB imediatamente, antes que ela gere complicações irreversíveis, como deformidade, fratura ou sequelas neurológicas. Mais comumente, suspeita-se da PBD após o achado incidental de níveis elevados de fosfatase alcalina no soro, ou anormalidades radiográficas em indivíduos aparentemente saudáveis com mais de 55 anos de idade. Alguns desses indivíduos podem apresentar sintomas, como a dor ou aumento ósseo com temperatura aumentada. Em geral, a avaliação laboratorial básica de metabolismo ósseo, radiografias simples dos ossos afetados e cintilografia óssea são suficientes para corroborar o diagnóstico. 0 tratamento antirreabsortivo com bifosfonatos é o principal tratamento da PDB sintomática, e o ácido zoledrônico intravenoso passou a ser uma opção de tratamento segura e eficiente, levando à manutenção da remissão e à melhora da qualidade de vida. É extremamente importante, entretanto, garantir níveis adequados de cálcio e vitamina $\mathrm{D}$ antes e durante o tratamento para se evitar a hipocalcemia. $\mathrm{O}$ benefício de se tratar todos os pacientes assintomáticos não está claro, mas o tratamento é recomendado se a localização da lesão pagética sugerir progressão para fratura, deformidade ou compressão que comprometam a qualidade de vida. Esta minirrevisão concentra-se em importantes aspectos do diagnóstico e tratamento da PDB. Arq Bras Endocrinol Metab. 2013;57(8):577-82

\section{Descritores}

Doença de Paget dos ossos; bifosfonatos; ácido zoledrônico; tratamento antirreabsortivo
1 Unidade de Doenças

Osteometabólicas e Laboratório de Investigação Médica 18 (LIM-18), Serviço de Endocrinologia, Hospital das Clínicas, Faculdade de Medicina da Universidade de São Paulo (HC-FMUSP), São Paulo, SP, Brazil
Correspondence to: Bruno Ferraz de Souza Av. Dr. Arnaldo, 455, sala 3324 (LIM-18)

01246-903 - São Paulo, SP, Brazil bruno.ferraz@hc.fm.usp.br bferrazd@gmail.com

Received on May/23/2013 Accepted on July/12/2013 


\section{INTRODUCTION}

$\mathrm{P}$ aget's disease of bone (PDB) is a localized disorder of bone remodeling resulting in abnormal bone architecture. It is a chronic and slowly progressive disorder involving a single bone location (monostotic) or more than one site (polyostotic). In general, PDB is found in individuals older than 55 years of age and a positive family history of the disease can be found in up to $15 \%$ of cases $(1,2)$.

$\mathrm{PDB}$ is a disorder of bone resorption, with increased numbers of activated multinucleated osteoclasts found in affected sites (3-5). In response to such increased bone resorption, there is a compensatory increment in bone formation. Due to the accelerated turnover rate, newly formed bone is large, disorganized (woven bone) and hypervascular, which explains the clinical findings of expansive, painful, and warm bone lesions.

The precise cause of PDB has not been fully defined, yet. There is a clear genetic predisposition, and several polymorphisms or mutations in key genes involved in osteoclastic differentiation or function, such as CSFI, TNFRSF11A, TNFRSF11B, TM7SF4, SQSTM1, VCP, and $O P T N$, have been associated with $\operatorname{PDB}(5,6)$. From these, mutations in SQSTMI (sequestosome 1 , also known as p62), a multifunctional intracellular protein involved in ubiquitination and NF-kappa-B signaling, have been identified in sporadic and familial cases, and confer a higher risk of $\operatorname{PDB}(7,8)$. On top of the genetic background, several environmental factors have been proposed as triggers of the development of a pagetic lesion (9). Among these, much attention has been paid to the role of paramyxovirus infection following the identification of intracellular inclusion bodies resembling paramyxoviral nucleocapsids in pagetic osteoclasts (10). Although in vitro evidence may implicate viral infection in the pathogenesis of $\mathrm{PDB}$, how important this mechanism is in vivo is still unclear.

PDB has a distinct epidemiology, and it is many times more common in the United Kingdom, continental Europe and countries of British ancestry than in other areas of the world. In high prevalence areas, PDB is the second most common disorder of bone metabolism (after osteoporosis) and may be present in up to 5\% of women and $8 \%$ of men above 80 years of age (11). Interestingly, the incidence of PDB in such areas has been declining over the last decades, suggesting that changes in environmental triggers may be modifying disease presentation (12). PDB is rare in Asia, Africa, and Scandinavia. In Brazil, data on its incidence are scarce. An analysis of nearly 8,000 patients followed up in a specialized institution in the city of Recife between 2006 and 2009 identified 53 individuals with $\mathrm{PDB}$, resulting in a total prevalence of 6.8 cases per 1,000 patients (13), which is equivalent to data from Southern Europe (14). Recently, a series of 134 cases recorded over a 15 -year period was reported in the city of Florianopolis (15). In our institution, in Sao Paulo, we have followed up approximately 45 cases of PDB in the past 15 years (unpublished data).

We present here a timely, succinct review of important aspects of the diagnosis and treatment of PDB. For further information, the reader is referred to previous reviews $(5,16-18)$.

\section{DIAGNOSIS OF PDB}

\section{Clinical presentation}

Most commonly, PDB is suspected upon the incidental finding of elevated serum alkaline phosphatase (ALP) levels or a radiographic abnormality in an otherwise healthy individual above 55 years of age. Thirty to forty percent of these individuals may have symptoms at presentation, such as bone pain, osteoarthritis, bone deformity with increased warmth or enlargement of the skull or mandible. The most frequently affected bone sites are the pelvis, lumbar vertebrae, femur, and the skull.

Individuals with PDB may already bear complications at diagnosis, such as fractures or neurological symptoms related to the location of the pagetic lesion including deafness, spinal cord or cranial nerve compression, or hydrocephalus $(19,20)$. High output congestive heart failure and sarcomatous transformation of the pagetic lesion are much rarer complications. Indeed, osteosarcomas occur in less than $0.5 \%$ of PDB patients, but should be suspected if sudden changes in symptoms (pain, deformity) are experienced (5). Another rare complication of PDB is hypercalcemia in patients immobilized for a long period (recovery of fracture, for example), thought to be due to unbalanced bone resorption in the absence of mechanical stimuli to bone formation.

Nevertheless, up to $95 \%$ of individuals with PDB may be completely asymptomatic. It is important to bear in mind, though, that even in such individuals, the disease is slowly progressive and may lead to symptoms 
and deformities in the future, as reported by Siris and Feldman on the 25-year follow-up of an asymptomatic patient (21).

\section{Laboratory evaluation}

The laboratory hallmark of PDB is increased serum ALP levels, mainly due to the extensive experience with the use of this easily obtainable bone formation marker. However, roughly $50 \%$ of serum ALP levels are attributable to a liver-specific isoform and, therefore, it is wise to analyze serum levels of transaminases and gamma-glutamyl transpeptidase concomitantly, in order to exclude liver abnormalities. Furthermore, up to $10 \%$ of patients with PDB can present normal ALP levels, and such finding should not rule out the diagnosis. More specific bone turnover markers, such as the commonly available serum C-terminal telopeptide (CTX) and urinary $\mathrm{N}$-terminal telopeptide (NTX), reflecting bone resorption, and aminoterminal propeptide of type 1 collagen (PINP), reflecting bone formation, can be useful in this setting. Determination of the nonisomerized fraction of CTX (alpha- or $\alpha$-CTX), which more accurately reflects the high turnover of pagetic woven bone (22), is unfortunately not widely available. It is expected that bone turnover markers will be more informative for the diagnosis and management of PDB in the future, as their usage in clinical practice increases; at the moment, however, they confer little additional benefit to the determination of serum ALP levels.

It is important to also assess sufficiency of vitamin $\mathrm{D}$ and calcium in these patients, as individuals in this age group are commonly vitamin D-deficient, and both hypocalcemia and hypovitaminosis $\mathrm{D}$ have been implicated as associated features and/or triggers of PDB. Indeed, even in individuals with normal serum calcium levels, normocalcemia is generally maintained at the expense of very high bone turnover rates and may not adequately reflect nutritional status. Finally, kidney function should also be assessed due to its implications for the choice of treatment, as it will be discussed. Table 1 provides a list of recommended laboratory tests for the diagnosis of PDB.

\section{Imaging}

Plain radiographies of affected bones and bone scintigraphy are most frequently used in diagnosing PDB. On radiography, the pagetic lesion may appear to be lytic, sclerotic or, commonly, both (Figure 1A). Cortices of long bones are thickened, and when the pelvis is affected, cortical thickening of the superior pubic ramus may often be seen. Typically, radiography of advanced PDB of the skull shows "cotton wool spots" corresponding to areas of bone sclerosis amid bone lysis (Figure $1 \mathrm{~B}$ ). Bone scintigraphy with Tc-99m-MDP shows an area of intense radionuclide uptake coinciding with the radiographic bone lesion, reflecting increased bone turnover and vascularity (Figure 2), and is particularly useful to identify additional sites in polyostotic $\mathrm{PDB}$, and to serve as a basal record for after-treatment comparison.

Computerized tomography and magnetic resonance imaging are not essential for the diagnosis of $\mathrm{PDB}$, but can be helpful when neurological symptoms of compression are present, or when there is clinical or radiographic suspicion of osteosarcoma.

\section{Differential diagnosis}

PDB should be differentiated from rarer disorders, such as fibrous dysplasia of bone, which normally affects individuals under 40 years of age, or hyperostosis frontalis interna, a benign affection of the skull. Arguably, the most important differential diagnosis of PDB is with blastic bony metastases, especially in view of the similar age group in which they occur. We usually request an orthopedic evaluation, often aided by CT/MRI or biopsy, to exclude metastasis in more difficult cases.

Table 1. Diagnostic tests for PDB

\begin{tabular}{ll}
\hline Laboratory evaluation & Alkaline phosphatase (ALP) (Gamma-glutamyl transpeptidase and transaminases may be useful to exclude liver-related abnormalities in ALP) \\
& Kidney function tests: serum creatinine and urea \\
& Evaluation of Ca nutritional status: total serum calcium, serum albumin, serum 25-hydroxyvitamin D and 24-h calciuria \\
& Bone turnover markers: CTX, NTX, and P1NP (helpful, but not essential) \\
& Plain radiographies of affected sites \\
Imaging & Bone scintigraphy with Tc-99m-MDP \\
& Computed tomography or magnetic resonance imaging of affected sites, if there are neurological symptoms or sarcomatous degeneration is \\
& suspected
\end{tabular}



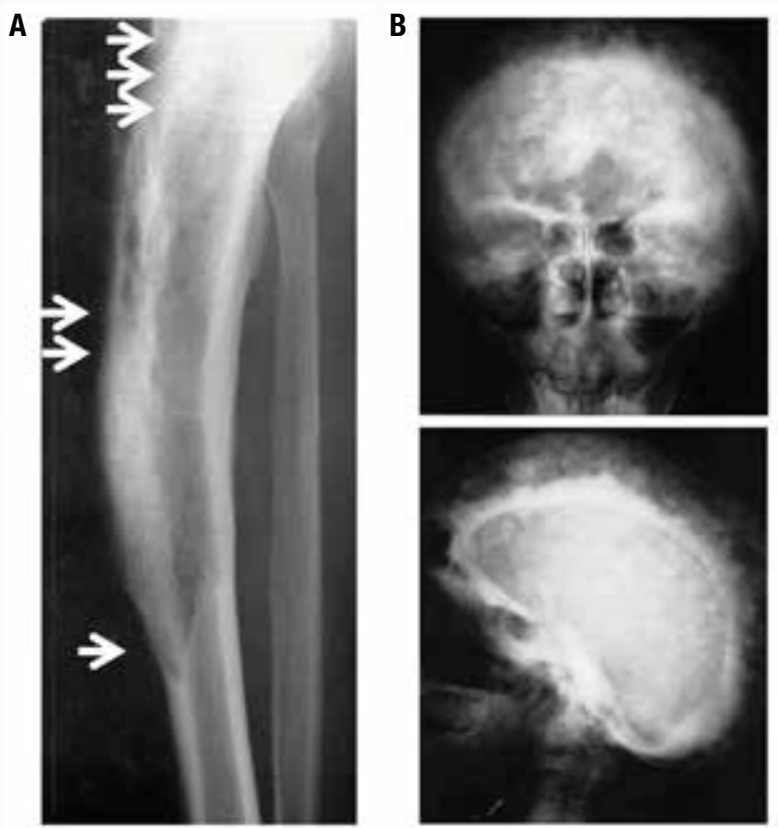

Figure 1. Plain radiographs of PDB. (A) Pagetic lesion of the fibula where a more lytic component (one arrow), corresponding to the bone resorption front, coexists with mixed (two arrows) and predominantly sclerotic (three arrows) components, as the disease progresses. (B) Extensive pagetic involvement of the skull, showing remarkable enlargement of the diploe and the typical "cotton wool spots" appearance due to areas of bone sclerosis amid bone lysis.

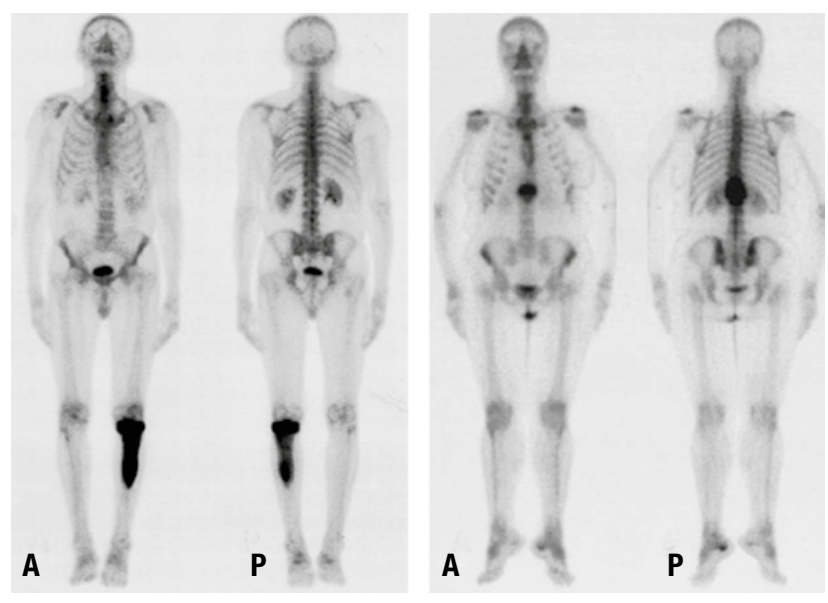

Figure 2. Bone scintigraphy with Tc-99m-MDP in two cases of monostotic PDB, showing areas of intense radionuclide uptake corresponding to the pagetic lesions in the fibula (left) and vertebra (right). (A) Anterior view; (P) Posterior view.

\section{TREATMENT OF PDB}

Antiresorptive therapy is the mainstay of PDB medical treatment, and its main objective is to achieve symptom relief, namely bone pain. Treatment is also indicated for immobilization-associated hypercalcemia and in prepa- ration for surgical procedures, as it is believed that it could reduce vascularization before surgery $(4,17,18)$. Surgical treatment of fractures or deformities may be a necessary complement to medical management, especially when neurological compression is detected.

As it was said, bone pain is the major indication for treatment. Considering that what is perceived by the patient as bone pain may actually be a manifestation of osteoarthritis, and that distinguishing one from the other is not always straightforward, an initial course of treatment is often warranted. If metabolic control is achieved after antiresorptive therapy but pain persists, specific treatment for osteoarthritis should be sought.

\section{Bisphosphonates}

Bisphosphonates are potent antiresorptive agents with high-affinity for bone and, thus, very effective in reducing metabolic activity and achieving symptomatic control in PDB $(18,21)$. Alendronate, risedronate, pamidronate, and zoledronic acid have proven efficacy (23-27) and can be used in the regimens shown in table 2 .

Few studies have conducted head-to-head comparison among bisphosphonates in the treatment of $\mathrm{PDB}$, and most findings are not compelling. Two identical 6-month randomized controlled trials comparing zoledronic acid with risedronate (27), and their extended analyses (28) are worth mentioning as they point at a likely benefit of using zoledronic acid due to a subtly superior improvement of quality of life and better performance in achieving sustained remission. Taken together with its favorable posology and safety, zoledronic acid is emerging as the treatment of choice for PDB.

Bisphosphonates are contraindicated if the glomerular filtration rate is below $35 \mathrm{~mL} / \mathrm{min}$. Common side effects include dyspepsia for oral agents (alendronate and, less frequently, risedronate), and flu-like symptoms for intravenous zoledronic acid and pamidronate. These symptoms occur 1 to 3 days after the infusion and can be minimized with analgesics/antipyretics. Potential complications of sustained suppression of bone turnover, such as osteonecrosis of the jaw or atypical fractures, have been reported but are seemingly very rare in PDB patients. Atrial fibrillation has been reported in association with zoledronic acid, but there is no formal contraindication in using this agent in elderly patients or those with cardiac disease (29). 
Table 2. Bisphosphonates with proven efficacy for antiresorptive treatment of PDB

\begin{tabular}{lccc}
\hline Drug & \multicolumn{1}{c}{ Dose } & Fall in ALP* & Reference \\
\hline Alendronate & $40 \mathrm{mg} /$ day, orally, for 6 months & 73 to $79 \%$ in 6 months & Siris 1996 (23) \\
& & & Reid 1996 (24) \\
Risedronate & $30 \mathrm{mg} /$ day, orally, for 2 months & $69 \%$ in 6 months & Miller 1999 (25) \\
Pamidronate & $60 \mathrm{mg} /$ day, intravenously, for 3 days & $53 \%$ in 6 months (different regimen) ${ }^{\star \star}$ & Walsh 2004 (26) \\
Zoledronic acid & $5 \mathrm{mg}$, intravenously, single dose & $\sim 80 \%$ in 6 months & Reid 2005 (27) \\
\hline
\end{tabular}

* Maximum fall in ALP levels with respective time to reach this level, as observed in pivotal randomized controlled trials listed in the 'reference' column.

** Walsh and cols. 2004 (26) treated patients with a single infusion of $60 \mathrm{mg}$ of pamidronate every 3 months.

It is crucial to ascertain calcium and vitamin D status prior to treatment of PDB with bisphosphonates, particularly with intravenous agents, and to implement vigorous supplementation before, during and after the treatment cycle. Hypocalcemia following bisphosphonate infusion is relatively frequent in patients with $\mathrm{PDB}$, owing to the acute suppression of resorption and subsequent drop in calcium outflow from the pagetic bone $(30,31)$. We have recently reported a patient with extensive PDB of the skull in whom, despite supplementation, acutely symptomatic and prolonged hypocalcemia ensued from zoledronic acid infusion (32). Therefore, we believe that, before intravenous bisphosphonates are administered to PDB patients, sufficient 25-hydroxyvitamin D levels should be guaranteed and daily calcium intake of calcium (diet plus supplements, if needed) should be greater than $1500 \mathrm{mg}$, resulting in normal-high serum calcium levels, and adequate calciuria $(2-4 \mathrm{mg} / \mathrm{kg}$ body weight in $24 \mathrm{~h})$.

\section{Other drugs}

Considering its mechanism of action and pharmacological properties, the RANKL-inhibitor denosumab seems very promising as an alternative antiresorptive agent in the treatment of PDB, particularly in patients with kidney impairment in whom the use of bisphosphonates is limited. A few case reports have documented its successful use (33), but randomized controlled trials are lacking.

In the meantime, if bisphosphonates cannot be used, calcitonin may provide symptom relief, but metabolic control is poor. Non-steroidal anti-inflammatory drugs (NSAIDS) can also be used for pain relief when antiresorptive therapy is not possible (34).

\section{Follow-up}

With successful treatment, it is expected that local or neurological symptoms will subdue, and metabolic activity will be normalized. Alkaline phosphatase levels should fall within the normal range, and bone scintigraphy, although not essential for follow-up, should show a reduction in radionuclide uptake in comparison to basal levels.

After undergoing an initial course of treatment with bisphosphonates, patients should be reassessed in 3 to 6 months if alendronate or risedronate are used; in 6 months, if pamidronate is used; and in one year, if zoledronic acid is used. If symptoms remain or return, or serum ALP levels rise above $75 \%$ of the normal upper limit, treatment should be repeated.

\section{Treatment of asymptomatic PDB}

At present, there is no evidence that treatment provides any benefit to asymptomatic patients. The PRISM trial randomized 1,324 patients in the United Kingdom to receive either symptomatic bisphosphonate treatment if pagetic bone pain did not respond to NSAIDS, or intensive bisphosphonate therapy aiming to keep ALP levels within the normal range, irrespective of symptoms (35). No differences in the occurrence of fractures, need for orthopedic surgery, quality of life, bone pain, or hearing thresholds were observed between the two groups. Most guidelines, therefore, only recommend treating PDB if symptoms are present (5).

Seminal studies by Delmas and Meunier in 1997 showed that bisphosphonate treatment is capable of correcting bone deposition in affected areas, leading to formation of lamelar bone and normalization of local bone architecture (3). Furthermore, it has been shown that asymptomatic disease progresses slowly and may eventually lead to complications (21). Hence, many specialists feel that treatment of asymptomatic patients is warranted, if the pagetic lesion is located in a site where fracture, deformity, or compression would significantly impair quality of life $(17,18,36)$. We tend to treat asymptomatic PDB patients if radiologic progression or metabolic worsening (increase in ALP) are detected during follow-up. 


\section{CONCLUSION}

Paget's disease of bone is a chronic progressive disorder of bone metabolism that may go undetected for many years. In Brazil, it is considered to be rare but precise estimates of nationwide incidence do not exist. Indeed, reports from south and northeast of the country support the idea that PDB might be more frequent than assumed in areas with clusters of European ancestry. It is important, thus, that endocrinologists are alert to its clinical signs and promptly recognize and diagnose PDB before it reaches more advanced stages with irreversible complications. Most cases respond very well to treatment with bisphosphonates in such a way that complications and deterioration of quality of life can be prevented in most cases. It is expected that, as the etiopathogenesis of PDB is better understood, new treatment options might become available and further improve patient care.

Acknowledgements: Bruno Ferraz-de-Souza holds a Young Investigator grant from the São Paulo Research Foundation (Fapesp; 2011/12696-4).

Disclosure: no potential conflict of interest relevant to this article was reported.

\section{REFERENCES}

1. Siris ES, Ottman R, Flaster E, Kelsey JL. Familial aggregation of Paget's disease of bone. J Bone Miner Res. 1991;6(5):495-500.

2. Seton M, Choi HK, Hansen MF, Sebaldt RJ, Cooper C. Analysis of environmental factors in familial versus sporadic Paget's disease of bone--the New England Registry for Paget's Disease of Bone. J Bone Miner Res. 2003;18(8):1519-24.

3. Delmas PD, Meunier PJ. The management of Paget's disease of bone. N Engl J Med. 1997;336(8):558-66.

4. Ralston $\mathrm{SH}$, Langston $\mathrm{AL}$, Reid IR. Pathogenesis and management of Paget's disease of bone. Lancet. 2008;372(9633):155-63.

5. Ralston SH. Clinical practice. Paget's disease of bone. N Engl J Med. 2013;368(7):644-50.

6. Albagha OM, Wani SE, Visconti MR, Alonso N, Goodman K, Brandi $\mathrm{ML}$, et al. Genome-wide association identifies three new susceptibility loci for Paget's disease of bone. Nat Genet. 2011;43(7):685-9.

7. Laurin N, Brown JP, Morissette J, Raymond V. Recurrent mutation of the gene encoding sequestosome 1 (SOSTM1/p62) in Paget disease of bone. Am J Hum Genet. 2002;70(6):1582-8.

8. Visconti MR, Langston AL, Alonso N, Goodman K, Selby PL, Fraser WD, et al. Mutations of SQSTM1 are associated with severity and clinical outcome in paget disease of bone. $J$ Bone Miner Res. 2010;25(11):2368-73.

9. Britton C, Walsh J. Paget disease of bone - an update. Aust Fam Physician. 2012;41(3):100-3.

10. Helfrich MH, Hocking LJ. Genetics and aetiology of Pagetic disorders of bone. Arch Biochem Biophys. 2008;473(2):172-82.

11. van Staa TP, Selby P, Leufkens HG, Lyles K, Sprafka JM, Cooper C. Incidence and natural history of Paget's disease of bone in England and Wales. J Bone Miner Res. 2002;17(3):465-71.

12. Cooper C, Harvey NC, Dennison EM, van Staa TP. Update on the epidemiology of Paget's disease of bone. J Bone Miner Res. 2006;21 Suppl 2:P3-8.
13. Reis RL, Poncell MF, Diniz ET, Bandeira F. Epidemiology of Paget's disease of bone in the city of Recife, Brazil. Rheumatol Int. 2012;32(10):3087-91.

14. Gennari L, Di Stefano M, Merlotti D, Giordano N, Martini G, Tamone $\mathrm{C}$, et al. Prevalence of Paget's disease of bone in Italy. $\mathrm{J}$ Bone Miner Res. 2005;20(10):1845-50.

15. Werner de Castro GR, Heiden GI, Zimmermann AF, Morato EF, Neves FS, Toscano MA, et al. Paget's disease of bone: analysis of 134 cases from an island in Southern Brazil: another cluster of Paget's disease of bone in South America. Rheumatol Int. 2012;32(3):627-31.

16. Griz L, Caldas G, Bandeira C, Assuncao V, Bandeira F. Paget's disease of bone. Arq Bras Endocrinol Metabol. 2006;50(4):814-22.

17. Siris ES, Lyles KW, Singer FR, Meunier PJ. Medical management of Paget's disease of bone: indications for treatment and review of current therapies. J Bone Miner Res. 2006;21 Suppl 2:P94-8.

18. Singer FR. Paget disease: when to treat and when not to treat. Nat Rev Rheumatol. 2009;5(9):483-9.

19. Bone HG. Nonmalignant complications of Paget's disease. J Bone Miner Res. 2006;21 Suppl 2:P64-8.

20. Rubin DJ, Levin RM. Neurologic complications of Paget disease of bone. Endocr Pract. 2009;15(2):158-66.

21. Siris ES, Feldman F. Natural history of untreated Paget's disease of the tibia. J Bone Miner Res. 1997;12(4):691-2.

22. Delmas PD. Biochemical markers of bone turnover in Paget's disease of bone. J Bone Miner Res. 1999;14 Suppl 2:66-9.

23. Siris E, Weinstein RS, Altman R, Conte JM, Favus M, Lombardi A, et al. Comparative study of alendronate versus etidronate for the treatment of Paget's disease of bone. J Clin Endocrinol Metab. 1996;81(3):961-7.

24. Reid IR, Nicholson GC, Weinstein RS, Hosking DJ, Cundy T, Kotowicz MA, et al. Biochemical and radiologic improvement in Paget's disease of bone treated with alendronate: a randomized, placebo-controlled trial. Am J Med. 1996;101(4):341-8.

25. Miller PD, Brown JP, Siris ES, Hoseyni MS, Axelrod DW, Bekker PJ. A randomized, double-blind comparison of risedronate and etidronate in the treatment of Paget's disease of bone. Paget's Risedronate/ Etidronate Study Group. Am J Med. 1999;106(5):513-20.

26. Walsh JP, Ward LC, Stewart GO, Will RK, Criddle RA, Prince RL, et al. A randomized clinical trial comparing oral alendronate and intravenous pamidronate for the treatment of Paget's disease of bone. Bone. 2004;34(4):747-54.

27. Reid IR, Miller P, Lyles K, Fraser W, Brown JP, Saidi Y, et al. Comparison of a single infusion of zoledronic acid with risedronate for Paget's disease. N Engl J Med. 2005;353(9):898-908.

28. Reid IR, Lyles K, Su G, Brown JP, Walsh JP, del Pino-Montes J, et al. A single infusion of zoledronic acid produces sustained remissions in Paget disease: data to 6.5 years. J Bone Miner Res. 2011;26(9):2261-70.

29. Pazianas M, Compston J, Huang CL. Atrial fibrillation and bisphosphonate therapy. J Bone Miner Res. 2010;25(1):2-10.

30. Rosen CJ, Brown S. Severe hypocalcemia after intravenous bisphosphonate therapy in occult vitamin D deficiency. N Engl J Med. 2003;348(15):1503-4.

31. Whitson HE, Lobaugh B, Lyles KW. Severe hypocalcemia following bisphosphonate treatment in a patient with Paget's disease of bone. Bone. 2006;39(4):954-8.

32. Ferraz-de-Souza B, Martin RM, Correa PH. Symptomatic intracranial hypertension and prolonged hypocalcemia following treatment of Paget's disease of the skull with zoledronic acid. J Bone Miner Metab. 2013;31(3):360-5.

33. Schwarz $P$, Rasmussen $A Q$, Kvist TM, Andersen UB, Jorgensen NR. Paget's disease of the bone after treatment with Denosumab: a case report. Bone. 2012;50(5):1023-5.

34. Lyles KW, Siris ES, Singer FR, Meunier PJ. A clinical approach to diagnosis and management of Paget's disease of bone. J Bone Miner Res. 2001;16(8):1379-87.

35. Langston AL, Campbell MK, Fraser WD, MacLennan GS, Selby $\mathrm{PL}$, Ralston SH. Randomized trial of intensive bisphosphonate treatment versus symptomatic management in Paget's disease of bone. J Bone Miner Res. 2010;25(1):20-31.

36. Reid IR, Cundy T, Bolland MJ, Grey A. Response to publication of PRISM trial. J Bone Miner Res. 2010;25(6):1463-4; author reply 5-6. 